\title{
A novel mechanism for the melatonin inhibition of testosterone secretion by rat Leydig cells: reduction of GnRH-induced increase in cytosolic $\mathrm{Ca}^{2+}$
}

\section{S Valenti ${ }^{1}$, S Thellung ${ }^{2}$, T Florio $^{2}$, M Giusti $^{1}$, G Schettini $^{2}$ and G Giordano ${ }^{1}$}

${ }^{1}$ Department of Endocrinology and Metabolism, University School of Medicine, Genova, 16132, Italy
${ }^{2}$ Institute of Pharmacology, University School of Medicine and Unit of Pharmacology and Neuroscience,
National Institute for Cancer Research (IST), Advanced Biotechnology Center (CBA), Genova, 16132,
Italy

(Requests for offprints should be addressed to S Valenti, DISEM, Viale Benedetto XV, 616132 , Genova-Italy)

\begin{abstract}
The site of inhibition, by melatonin, of GnRHdependent testosterone secretion was investigated in adult rat Leydig cells cultured in vitro. The various effects downstream of the binding of GnRH to its own receptor were isolated and mimicked by specific drugs. Testosterone secretion was then evaluated after $3 \mathrm{~h}$ stimulation with GnRH, thapsigargin $(1 \mu \mathrm{M})$, phorbol-12-myristate-13acetate $(100 \mathrm{nM})$, arachidonic acid $(20 \mu \mathrm{M})$, and ionomycin $(1 \mu \mathrm{M})$ in the presence or absence of melatonin $(215 \mathrm{nM})$. The effect of melatonin on the GnRH-induced changes in cytoplasmic calcium concentration $\left(\left[\mathrm{Ca}^{2+}\right]_{\mathrm{i}}\right)$ was also studied, using Fura-2 as fluorescent $\mathrm{Ca}^{2+}$ indicator. Melatonin attenuated the increase in $\left[\mathrm{Ca}^{2+}\right]_{i}$ and inhibited the testosterone secretion induced by $\mathrm{GnRH}$, but not that induced by ionomycin. Both ionomycin and thapsigargin potentiated $\mathrm{GnRH}$-induced testosterone secretion; however, ionomycin, but not
\end{abstract}

thapsigargin, partially prevented the inhibitory effect of melatonin on cells stimulated with GnRH. The effect of melatonin was probably dependent on the binding of melatonin to its $\mathrm{Gi}$-protein-coupled receptor, as the inhibitory effect on GnRH-induced secretion was supressed in cells pretreated with pertussis toxin in a concentration of $180 \mathrm{ng} / \mathrm{ml}$ for $20 \mathrm{~h}$. Assay of 17-hydroxy-progesterone showed that, irrespective of the treatment, cells cultured with melatonin secreted greater amounts than controls. We conclude that melatonin reduces GnRH-induced testosterone secretion by 1) decreasing $\left[\mathrm{Ca}^{2+}\right]_{\mathrm{i}}$, through impairment of the $\mathrm{GnRH}$-dependent release of $\mathrm{Ca}^{2+}$ from intracellular stores and 2) blocking 17-20 desmolase enzymatic activity, an effect that occurs irrespective of changes in $\left[\mathrm{Ca}^{2+}\right]_{\mathrm{i}}$.

Fournal of Molecular Endocrinology (1999) 23, 299-306

\section{INTRODUCTION}

Testosterone production by Leydig cells is stimulated not only by luteinizing hormone $(\mathrm{LH})$, which activates the cAMP pathway, but also by several endocrine and paracrine factors, which can act through non-cAMP-dependent pathways (Saez 1994). Among these, gonadotropin-releasing hormone $(\mathrm{GnRH})$ exerts its action through a complex interplay of signalling pathways, the final results being an increase in cytosolic $\mathrm{Ca}^{2+}$ concentrations and activation of protein kinase $\mathrm{C}$ (PKC) - probably more relevant for the stimu- lation of testosterone secretion. After the binding of $\mathrm{GnRH}$ to its own receptor, inositol triphosphate $\left(\mathrm{IP}_{3}\right)$ and diacylglycerol (DAG) are produced through activation of phospholipase $\mathrm{C}$ (PLC). $\mathrm{IP}_{3}$ releases calcium from the intracellular stores, and DAG directly regulates the activity of PKC (Leung \& Steele 1992, Rasmussen et al. 1995). Some DAG may be hydrolysed by DAG lipase to produce arachidonic acid; generation of the latter also occurs after activation of phospholipase A2 $\left(\mathrm{PLA}_{2}\right)$ by $\mathrm{GnRH}$, and can directly stimulate androgen secretion (Lin 1985, Romanelli et al. 1995). 
Melatonin has been shown to modulate directly the in vitro secretion of testosterone by rat (Ellis 1972, Ng \& Lo 1988, Valenti et al. 1995) and human Leydig cells (Giusti et al. 1997). Indeed, after binding to its pertussis-toxin-sensitive receptor, melatonin reduces $\mathrm{LH}$-stimulated testosterone secretion by inhibiting adenylyl cyclase activity (Valenti et al. 1997). However, melatonin is also likely to influence non-cAMP mediated testosterone secretion, as it reduces GnRH-dependent testosterone secretion also (Valenti et al. 1995, 1997). A comparable effect of melatonin has been noted by Vanececk (1998) in the control of GnRH-induced LH secretion from neonatal rat gonadotrophs; in these cells, melatonin inhibits the GnRH-induced increase in $\mathrm{Ca}^{2+}$ by interfering both with the mobilization of $\mathrm{Ca}^{2+}$ from intracellular stores and with the subsequent entry of extracellular $\mathrm{Ca}^{2+}$.

In the present study, the mechanism(s) by which melatonin affects GnRH-mediated testosterone secretion has therefore been investigated. To this end, the effects evoked by GnRH downstream of the binding to its receptor were separated into several components, which were mimicked by specific drugs. Subsequently, the effect of melatonin was tested on the secretion of testosterone induced by the naturally occurring sequiterpene lactone, thapsigargin, which increases intracellular calcium concentrations (Putney \& Bird 1993), phorbol myristate acetate (PMA), which directly activates PKC (Foresta et al. 1995), the ionophore, ionomycin, which allows extracellular calcium entry (Pereira et al. 1988), and direct administration of arachidonic acid, which directly stimulates testosterone secretion (Lin 1985, Romanelli et al. 1995). Moreover, the effect of melatonin on the GnRHinduced changes in cytoplasmic $\mathrm{Ca}^{2+}$ concentrations was studied by using the fluorescent $\mathrm{Ca}^{2+}$ indicator, Fura-2.

\section{MATERIALS AND METHODS}

\section{Chemicals}

Collagenase (type IA), soybean trypsin inhibitor, leupeptin, BSA (fraction V), PMA, arachidonic acid, thapsigargin, ionomycin, and pertussis toxin (PTX) were purchased from Sigma Chemical Co. (St Louis, MO, USA); melatonin was obtained from Bachem (Torrance, CA, USA); human LH was obtained from the National Institute for Biological Standards and Control (Potters Bar, UK); GnRH was purchased from Serono (Rome, Italy). Percoll was obtained from Pharmacia (Uppsala, Sweden); medium 199 and Hanks' balanced salt solution (HBSS) were obtained from
Gibco (Grand Island, NY, USA). Fura-2 acetoxymethyl ester (Fura-2) was purchased from Calbiochem (La Jolla, CA, USA).

\section{Leydig cell purification}

Adult male Wistar rats (70 days old), obtained from Morini (S Polo d'Enza, Italy) were maintained on a $12 \mathrm{~h}$ light: $12 \mathrm{~h}$ darkness cycle (lights on 0600$1800 \mathrm{~h}$ ). All experiments were performed soon after the death of the rat, which took place at $0900 \mathrm{~h}$. Leydig cell purification was performed as previously described (Conte et al. 1993). Immediately after death, the testes were removed and infused, via the testicular artery, with an enzyme solution (collagenase $0.5 \mathrm{mg} / \mathrm{ml}$, soybean trypsin inhibitor $0 \cdot 2 \mathrm{mg} / \mathrm{ml}$, and leupeptin $5 \mu \mathrm{g} / \mathrm{ml}$ in HBSS containing $0 \cdot 1 \%(\mathrm{wt} / \mathrm{vol}) \mathrm{BSA}, \mathrm{pH} 7 \cdot 4)$ and then dispersed in enzyme solution in a shaking waterbath $(20 \mathrm{~min} ; 90$ cycles $/ \mathrm{min} ; 34^{\circ} \mathrm{C}$ ). After the dissociated tubules had been allowed to settle, the supernatants were filtered, washed and centrifuged. The pellet was resuspended, applied to a discontinuous Percoll density gradient and centrifuged. Leydig cells that migrated to the $43-68 \%$ interface (specific gravity 1.064 $1.096 \mathrm{~g} / \mathrm{ml}$ ) were collected, resuspended in medium 199 and centrifuged once more. The percentage of Leydig cells obtained was $78 \pm 6 \%$, as determined by histochemical staining for $3 \beta$-hydroxysteroid dehydrogenase, and cell viability was $>90 \%$, as determined by trypan blue exclusion. Cells were counted in haemocytometer, aliquoted in 96-well plates $\left(4 \times 10^{4} / 0 \cdot 2 \mathrm{ml}\right.$ medium 199 per well $)$, and allowed to attach during $1 \mathrm{~h}$ of preincubation at $37^{\circ} \mathrm{C}$ in an atmosphere of $95 \% \mathrm{O}_{2}$ and $5 \% \mathrm{CO}_{2}$.

\section{Cell cultures}

Cells were incubated for $3 \mathrm{~h}$ with increasing doses of the drugs to be tested. One optimal dose was selected for each substance and used in further experiments, which were conducted in the presence or absence of melatonin $215 \mathrm{nM} \quad(50 \mathrm{ng} / \mathrm{ml})$. Thapsigargin and ionomycin were added $15 \mathrm{~min}$ before administration of $\mathrm{GnRH}$, melatonin, or both. To test whether the effect exerted by melatonin was mediated by the binding of the indole to its own membrane receptor coupled to a PTX-sensitive Gi protein, some experiments were repeated with cells pretreated or not with PTX (180 ng/ml for $20 \mathrm{~h})$. PMA was used as a factor able to induce secretion of testosterone through direct activation of PKC. To confirm the involvment of $\mathrm{PKC}$, some experiments were performed in the presence of the $\mathrm{PKC}$ inhibitor, staurosporine $(30 \mathrm{nM}$, administered 30 min before the stimuli) in basal conditions and 
during stimulation with GnRH, PMA and LH $(20 \mathrm{mIU} / \mathrm{ml})$. Finally, the role of melatonin on arichidonic acid-dependent testosterone secretion was evaluated, by administering the drug in a dose of $20 \mu \mathrm{M}$.

\section{Cytoplasmic $\mathrm{Ca}^{2+}$ measurements}

Leydig cells were seeded on coverslips placed in individual Petri dishes $(2 \mathrm{ml} / \mathrm{dish})$ and allowed to attach for $60 \mathrm{~min}$ at $37^{\circ} \mathrm{C}$. After a 10 -min wash, cells were loaded with $4 \mu \mathrm{M}$ Fura-2 for $30 \mathrm{~min}$ at room temperature to avoid probe compartmentalization (Malgaroli et al. 1987), and then washed again for $10 \mathrm{~min}$. Coverslips were mounted on a coverslip chamber for fluorescence measurement, which was performed at room temperature in medium 199, on individual fields of 25-30 cells each. To test the effects of melatonin, the hormone was added to the medium 199 in a dose of $10 \mu \mathrm{M}$ during the loading period and throughout the experiment. Each cell in the image was independently analysed for each timepoint in the captured sequence. For the calibration of fluorescent signals, cells loaded with Fura- 2 were used. $R_{\max }$ and $R_{\min }$ are ratios at saturating and zero $\left[\mathrm{Ca}^{2+}\right]_{\mathrm{i}}$ respectively, and were obtained by perfusing cells with standard buffer containing $10 \mathrm{mM} \mathrm{CaCl}, 5 \mu \mathrm{M}$ ionomycin and, subsequently, a $\mathrm{Ca}^{2+}$-free solution containing $20 \mathrm{mM}$ EGTA and $40 \mathrm{mM}$ Tris. The values of $\mathrm{R}_{\max }$ and $\mathrm{R}_{\min }$, expressed as a grey-level mean, were used to calculate the calibration curve by mean of TARDIS software (Scorziello et al. 1997). $\left[\mathrm{Ca}^{2+}\right]_{\mathrm{i}}$ was determined according to the equation of Grynkiewicz et al. (1985).

\section{RIAs}

Testosterone and 17-hydroxyprogesterone (OHP) were assayed by RIA (Diagnostic Product Corp., Los Angeles, CA, USA) as previously reported (Valenti et al. 1997). The sensitivity level for testosterone was $0.52 \mathrm{nM} / 1$ and the intra-assay coefficient of variation $(\mathrm{CV})$ was $5 \cdot 3 \%$ at $1.42 \mathrm{nM} / 1$; for $\mathrm{OHP}$, sensitivity was $0 \cdot 3 \mathrm{nM} / 1$ and the $\mathrm{CV}$ was $7 \cdot 8 \%$ at $2.4 \mathrm{nM} / \mathrm{l}$. None of the substances tested interfered with the assays.

\section{Statistics}

Data from at least three experiments were pooled, analysed by ANOVA followed by unpaired Student's $t$-test and expressed as mean \pm s.E.M. For comparison of multiple treatment groups with a single control group, Dunnett's post hoc test was applied. Significance was taken as $P<0 \cdot 05$.

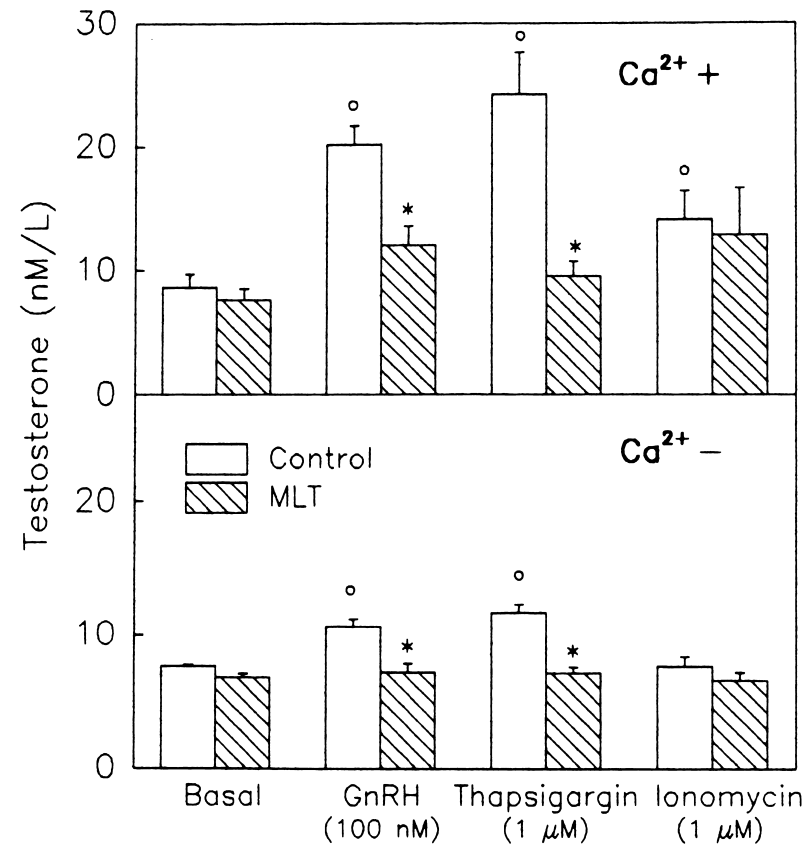

FIGURE 1. Testosterone secretion recorded after $3 \mathrm{~h}$ of incubation in basal conditions and during stimulation with $\mathrm{GnRH}$, thapsigargin and ionomycin, by control cells and cells cultured in the presence of melatonin (MLT) (215 nM). Experiments were performed in the presence (upper panel) and in the absence (lower panel) of extracellular $\mathrm{Ca}^{2+}$. Significant differences from ${ }^{\circ}$ basal and *ontrol cells $(P<0 \cdot 05)$.

\section{RESULTS}

\section{Effect of melatonin on testosterone release stimulated by $\mathrm{GnRH}$ and $\mathrm{Ca}^{2+}$ mobilizing stimuli}

A dose-dependent increase in testosterone secretion was noted during incubation with increasing concentrations of $\mathrm{GnRH}(1 \mathrm{nM}-1 \mu \mathrm{M})$, thapsigargin (0.01-1 $\mu \mathrm{M})$ and ionomycin $(0 \cdot 01-1 \mu \mathrm{M})$.

The concentrations selected for the present experiments were $100 \mathrm{nM}$ for $\mathrm{GnRH}$ and $1 \mu \mathrm{M}$ for thapsigargin and ionomycin; in the presence of melatonin $(215 \mathrm{nM})$, the testosterone secretion evoked by $\mathrm{GnRH}$ and thapsigargin was significantly reduced, whereas melatonin did not affect the testosterone secretion elicited by administration of ionomycin. The results of these experiments are shown in Fig. 1, upper panel. In $\mathrm{Ca}^{2+}$-free medium, $\mathrm{GnRH}$ and thapsigargin still increased testosterone secretion, although to a lower extent than that recorded in medium 199, and administration of melatonin suppressed this secretion. In contrast, ionomycin administered to cells cultured in 


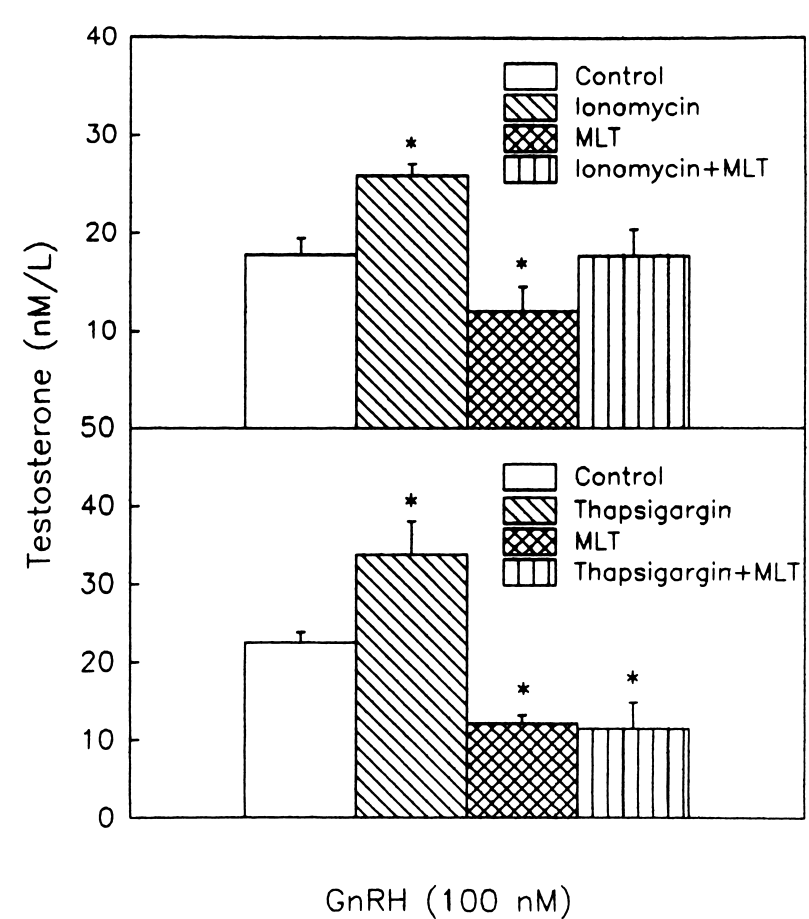

FIGURE 2. Upper panel: GnRH-induced testosterone secretion as recorded after $3 \mathrm{~h}$ of incubation with $\mathrm{GnRH}$ alone (Control) or with the addition of ionomycin $(1 \mu \mathrm{M})$, melatonin (MLT) $(215 \mathrm{nM})$ or ionomycin+MLT.

*Significant difference from controls $(P<0 \cdot 05)$. Lower panel: GnRH-induced testosterone secretion as recorded after $3 \mathrm{~h}$ of incubation with $\mathrm{GnRH}$ alone (Control) or with the addition of thapsigargin $(1 \mu \mathrm{M})$, MLT $(215 \mathrm{nM})$ or thapsigargin+MLT. *Significant difference from controls $(P<0 \cdot 05)$.

$\mathrm{Ca}^{2+}$-free medium did not significantly influence testosterone secretion, and the effect of melatonin was noticeable. These results are shown in the lower panel of Fig. 1.

Ionomycin administered to cells bathed in medium 199 suppressed the inhibitory effect of melatonin on GnRH-dependent testosterone secretion; indeed, cells incubated with ionomycin+ melatonin $+\mathrm{GnRH}$ secreted an amount of testosterone similar to that secreted by those cells treated with GnRH alone (Fig. 2, upper panel). The use of increasing concentrations of ionomycin did not reverse this effect; indeed, irrespective of the concentrations of the ionophore administered, testosterone secretion by cells incubated with $\mathrm{GnRH}$ and melatonin always lagged behind that of cells cultured with GnRH (data not shown). Furthermore, concentrations of ionomycin greater than $10 \mu \mathrm{M}$ resulted in impaired testosterone secretion, possibly because of a toxic effect of

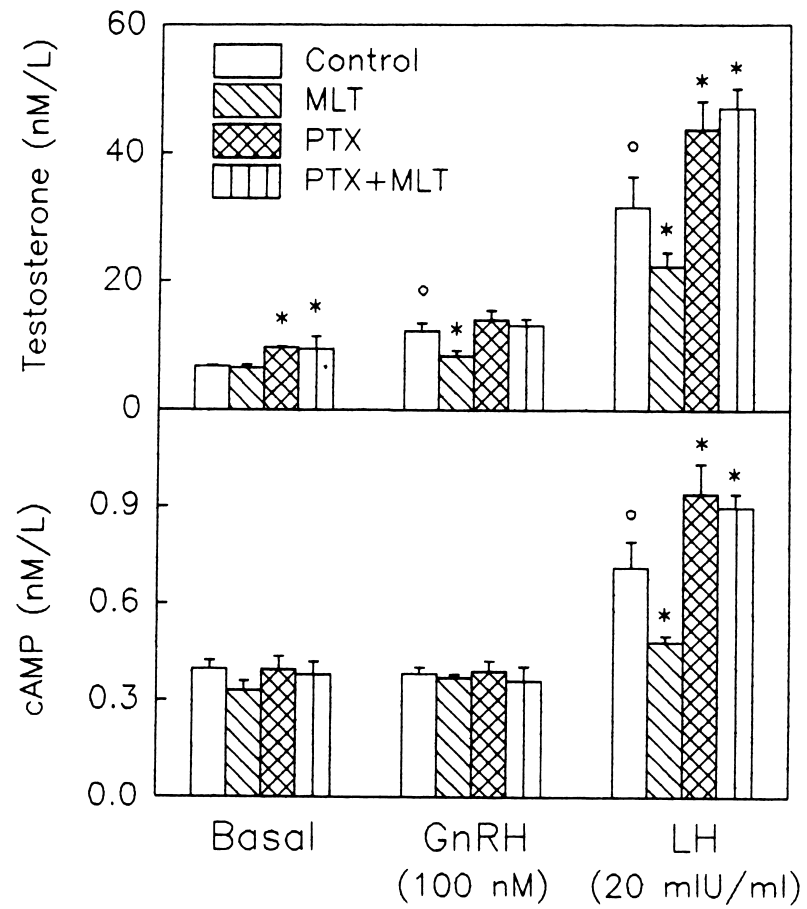

FIGURE 3. The effect of administration of melatonin (MLT) on secretion of testosterone (upper panel) and cAMP (lower panel) by cells incubated in basal conditions or with GnRH and LH. Cells had been preincubated in the presence (PTX and PTX+MLT) or in the absence (Control and MLT) of PTX (180 ng/ml for $20 \mathrm{~h}$ ) and washed before $3 \mathrm{~h}$ incubation in the presence (PTX+MLT and MLT) or in the absence (Control and PTX) of MLT (215 nM/l). Significant difference from ${ }^{\circ}$ basal and ${ }^{*}$ Controls $(P<0 \cdot 05)$.

the drug at these concentrations. In contrast, thapsigargin was not able to prevent the inhibitory effect exerted by melatonin on GnRH-dependent testosterone secretion, either at the dose reported in the lower panel of Fig. 2, or in greater concentrations (data not shown).

To test whether the effect of melatonin was mediated by the binding of the indole to its own Gi-protein-coupled membrane receptor, some experiments were repeated after pretreatment with PTX in a concentration of $180 \mathrm{ng} / \mathrm{ml}$ for $20 \mathrm{~h}$. As a result of PTX pretreatment, basal and LH-stimulated testosterone secretions were greater than those recorded in controls; furthermore, the inhibitory effect of melatonin on GnRH- and LH-stimulated secretion was eliminated. cAMP secretion was comparable to that recorded in controls, both in the basal condition and during GnRH-stimulation, but varied according to the changes in testosterone secretion during 


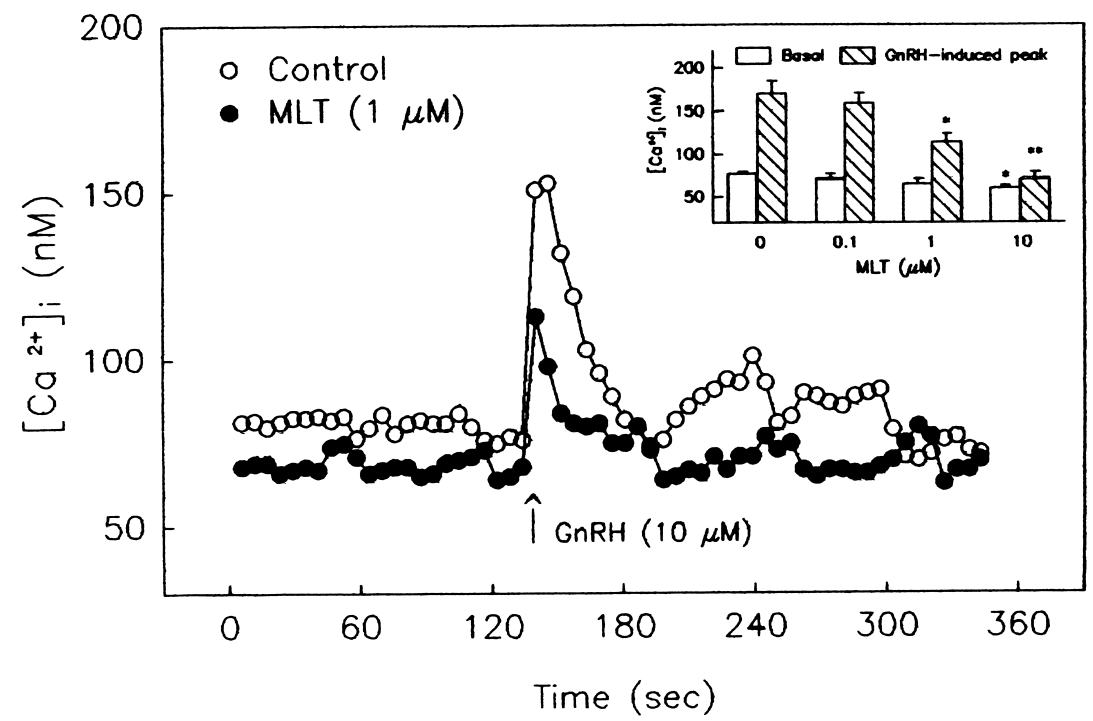

FIGURE 4. Mean $\left[\mathrm{Ca}^{2+}\right]_{\mathrm{i}}$ as recorded over $360 \mathrm{~s}$ from 200 control cells $(\bigcirc)$ and 200 cells incubated with melatonin (MLT) $(1 \mu \mathrm{M}, \mathbf{O})$. Acutely added GnRH $(10 \mu \mathrm{M})$ evoked a rapid and transient $\left[\mathrm{Ca}^{2+}\right]_{\mathrm{i}}$ spike; in the presence of MLT, basal $\left[\mathrm{Ca}^{2+}\right]_{\mathrm{i}}$ and the $\mathrm{GnRH}$-induced $\left[\mathrm{Ca}^{2+}\right]_{\mathrm{i}}$ spike were reduced. Insert: Basal $\left[\mathrm{Ca}^{2+}\right]_{\mathrm{i}}$ and $\mathrm{GnRH}$-induced $\left[\mathrm{Ca}^{2+}\right]_{\mathrm{i}}$ peak in the absence or presence of increasing concentrations of $\operatorname{MLT}(0 \cdot 1-10 \mu \mathrm{M})$ (means of four experiments). Significant differences from the corresponding control incubated without MLT: $* P<0 \cdot 05, * * P<0 \cdot 01$.

administration of LH. These results are presented in Fig. 3.

\section{Effect of melatonin on direct cytoplasmic $\mathrm{Ca}^{2+}$ measurement}

Mean $\left[\mathrm{Ca}^{2+}\right]_{\mathrm{i}}$ concentrations recorded from five experiments for controls and melatonin-treated cells in response to $\mathrm{GnRH}$ administration are shown Fig. 4. Addition of GnRH $(10 \mu \mathrm{M})$ caused a rapid and transient increase in $\left[\mathrm{Ca}^{2+}\right]_{\mathrm{i}}$ in $38 \%$ of the cells observed; after the spike response, $\left[\mathrm{Ca}^{2+}\right]_{\mathrm{i}}$ returned to basal values within $60 \mathrm{~s}$. Cells incubated in the presence of melatonin $(1 \mu \mathrm{M})$ showed significantly lower basal $\left[\mathrm{Ca}^{2+}\right]_{\mathrm{i}}$ concentrations and a significant reduction in the peak amplitude after GnRH administration; however, melatonin administration did not influence the number of cells responsive to GnRH (39\%) in comparison with the control group. Comparable results were noted in $\mathrm{Ca}^{2+}$-free medium (data not shown).

The inhibitory effect of melatonin on the GnRH-dependent increase in intracellular $\mathrm{Ca}^{2+}$ was a dose-dependent phenomenon, and appeared for concentrations of melatonin greater than $0 \cdot 1 \mu \mathrm{M}$ (insert to Fig. 4).
Effects of melatonin on testosterone secretion dependent on direct PKC stimulation and exogenous arachidonic acid administration

PMA increased the testosterone secretion in a dosedependent manner $(0 \cdot 01-10 \mu \mathrm{M})$; the concentration of $100 \mathrm{nM}$ was selected for these experiments. Administration of melatonin did not change testosterone secretion in the basal condition or in the presence of staurosporine, a blocker of PKC activity (data not shown); however, melatonin administration did reduce GnRH- and PMAstimulated testosterone secretion. In the presence of staurosporine, PMA- and GnRH-dependent testosterone production were reduced by $30 \%$ and $40 \%$ respectively, whereas spontaneous or LHstimulated $(30 \mathrm{mIU} / \mathrm{ml})$ testosterone secretions were unaffected by staurosporine. The results of these experiments are shown in Fig. 5.

Arachidonic acid administered in a concentration of $20 \mu \mathrm{M}$ increased testosterone release by approximately $50 \%$; melatonin impaired this secretion of testosterone (Fig. 6).

\section{Effect of melatonin on 17-hydroxy-progesterone}

OHP concentrations were recorded from the experiments described; they are summarized in 


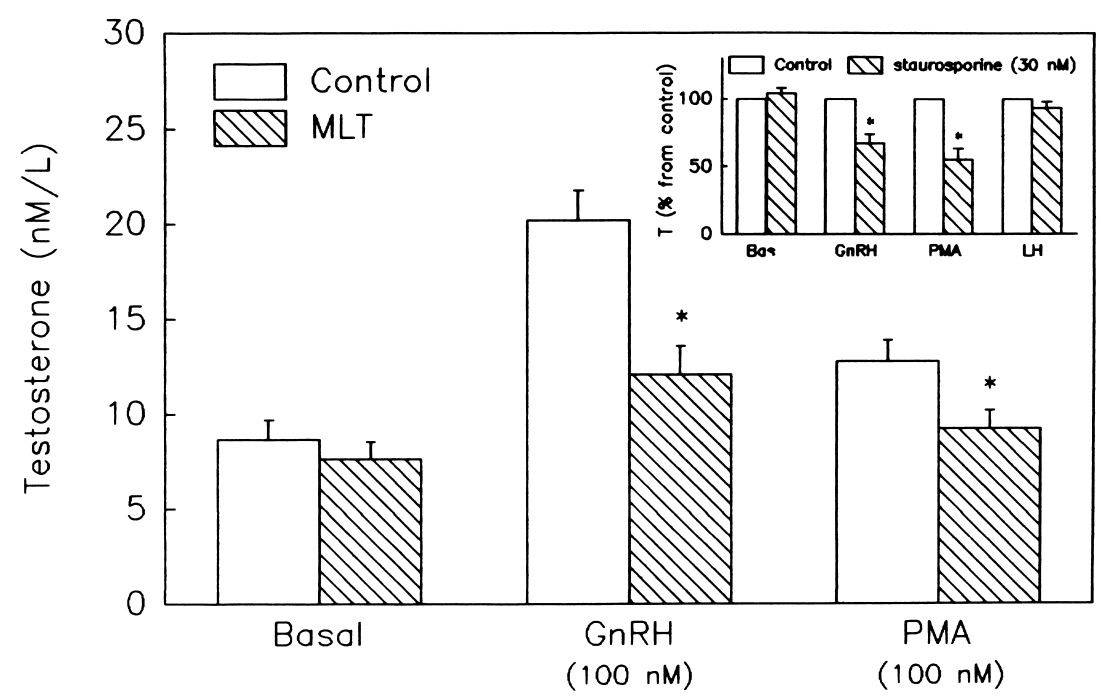

FIGURE 5. Secretion of testosterone recorded after $3 \mathrm{~h}$ of incubation in basal conditions and during stimulation with $\mathrm{GnRH}$ and PMA, by control cells and cells cultured in the presence of melatonin (MLT) $(215 \mathrm{nM})$. Insert: Testosterone secretion recorded in basal conditions, in the presence of GnRH (100 nM), PMA (100 nM) and LH $(20 \mathrm{mIU} / \mathrm{ml})$ for control cells and cells preincubated with staurosporine $(30 \mathrm{nM}$ for $30 \mathrm{~min})$. These results are expressed as percentage from control cells. * Significant difference from control cells $(P<0 \cdot 05)$.

Table 1, together with testosterone concentrations. All the stimuli used increased OHP concentrations over the corresponding basal values, both in the presence and in the absence of melatonin. However, irrespective of the drug administered, OHP concentrations were always three- to fourfold greater in the media harvested from cells treated with melatonin than in their corresponding controls, and the secretion of testosterone was significantly reduced.

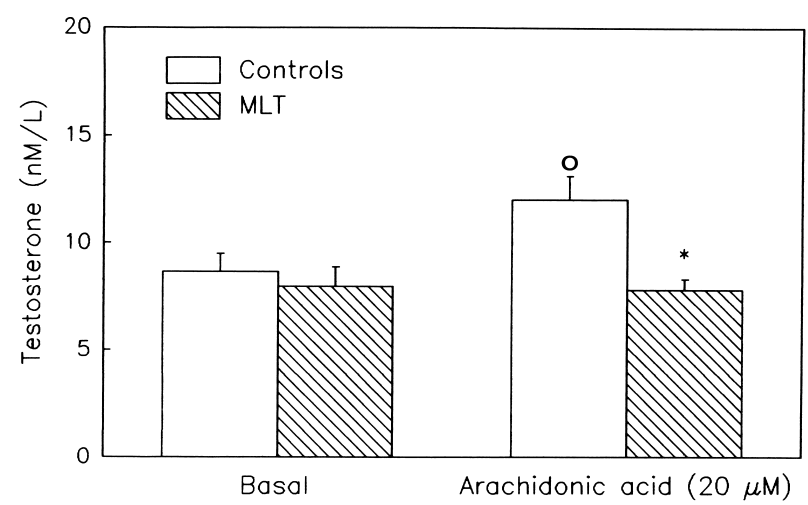

FIGURE 6. Testosterone secretion as recorded after $3 \mathrm{~h}$ of incubation in basal conditions and during stimulation with arachidonic acid in the presence or absence of melatonin (MLT) $(215 \mathrm{nM})$. Significant differences from ${ }^{\circ}$ basal and ${ }^{*}$ Control cells $(P<0 \cdot 05)$.

\section{DISCUSSION}

This study has shown that melatonin inhibits GnRH-dependent testosterone secretion, in part by decreasing the cytoplasmic $\mathrm{Ca}^{2+}$ concentrations in rat Leydig cells cultured in vitro. In our experiments, melatonin blocked the testosterone secretion induced by $\mathrm{GnRH}$ and thapsigargin, which release $\mathrm{Ca}^{2+}$ ions from intracellular stores, and this inhibitory effect of melatonin was also observed in the absence of extracellular calcium.

When administered to cells bathed in medium 199, the ionophore, ionomycin, was capable of reversing the inhibitory effect of melatonin on testosterone secretion. Ionomycin, by allowing transmembrane $\mathrm{Ca}^{2+}$ influx, replenishes the intracellular $\mathrm{Ca}^{2+}$ stores, which are likely to be depleted within a few minutes ( $\mathrm{Li}$ et al. 1994, Foresta et al. 1996), and thus enables steroidogenesis to occur. Indeed, although the early response to $\mathrm{GnRH}$ in Leydig cells involves mobilization of $\mathrm{Ca}^{2+}$ from the intracellular stores without requiring extracellular $\mathrm{Ca}^{2+}$ influx (Tomic et al. 1995), steroidogenesis has been demonstrated to be highly dependent on the extracellular $\mathrm{Ca}^{2+}$ influx, as studies performed in $\mathrm{Ca}^{2+}$-free medium or in the presence of verapamil, an antagonist of $\mathrm{Ca}^{2+}$ channels, have demonstrated (Sullivan \& Cooke 1986, Foresta et al. 1996). Both ionomycin and thapsigargin augmented the 
TABLE 1. Concentration of 17-hydroxy-progesterone (OHP) and testosterone (T) as determined after incubation of Leydig cells for $3 \mathrm{~h}$ in the presence of various stimuli

\begin{tabular}{|c|c|c|c|c|}
\hline & \multicolumn{2}{|l|}{ Controls } & \multicolumn{2}{|l|}{ MLT } \\
\hline & $\mathrm{OHP}(\mathrm{nM} / \mathrm{l})$ & $\mathrm{T}(\mathrm{nM} / \mathrm{l})$ & $\mathrm{OHP}(\mathrm{nM} / \mathrm{l})$ & $\mathrm{T}(\mathrm{nM} / \mathrm{l})$ \\
\hline \multicolumn{5}{|l|}{ Stimulus } \\
\hline Basal & $0 \cdot 28 \pm 0 \cdot 05$ & $8 \cdot 65 \pm 1 \cdot 03$ & $1 \cdot 01 \pm 0 \cdot 15 \uparrow$ & $7 \cdot 61 \pm 0 \cdot 92 \dagger$ \\
\hline GnRH (100 nM) & $0 \cdot 55 \pm 0 \cdot 05^{*}$ & $20 \cdot 20 \pm 1 \cdot 55^{*}$ & $2 \cdot 44 \pm 0 \cdot 16^{*}, \dagger$ & $12 \cdot 05 \pm 1 \cdot 51 * . \dagger$ \\
\hline PMA (100 nM) & $0 \cdot 34 \pm 0 \cdot 08$ & $12 \cdot 75 \pm 1 \cdot 13^{*}$ & $1 \cdot 19 \pm 0 \cdot 20 \dagger$ & $9 \cdot 21 \pm 0 \cdot 98 \dagger$ \\
\hline $\mathrm{AA}(20 \mu \mathrm{M})$ & $0 \cdot 36 \pm 0 \cdot 02 *$ & $10 \cdot 01 \pm 1 \cdot 07 *$ & $1 \cdot 25 \pm 0 \cdot 15^{*} . \dagger$ & $7 \cdot 77 \pm 0 \cdot 38 \uparrow$ \\
\hline Thapsigargin $(1 \mu \mathrm{M})$ & $0.76 \pm 0.09 *$ & $24 \cdot 22 \pm 3 \cdot 46^{*}$ & $2 \cdot 10 \pm 0 \cdot 25^{*} . \dagger$ & $9 \cdot 51 \pm 1 \cdot 21 \dagger$ \\
\hline Thapsigargin $+\mathrm{GnRH}$ & $1 \cdot 53 \pm 0 \cdot 30 *$ & $33 \cdot 73 \pm 4 \cdot 32 *$ & $7 \cdot 25 \pm 1 \cdot 25^{*} . \dagger$ & $11 \cdot 42 \pm 3 \cdot 46^{*} . \dagger$ \\
\hline Ionomycin $(1 \mu \mathrm{M})$ & $0 \cdot 86 \pm 0 \cdot 10^{*}$ & $14 \cdot 01 \pm 2 \cdot 35^{*}$ & $2 \cdot 67 \pm 0 \cdot 35^{*} . \dagger$ & $12 \cdot 87 \pm 3 \cdot 80 *$. \\
\hline Ionomycin $+\mathrm{GnRH}$ & $1 \cdot 65 \pm 0 \cdot 28 *$ & $25 \cdot 95 \pm 1 \cdot 21 *$ & $6 \cdot 07 \pm 1 \cdot 37 * . \dagger$ & $17 \cdot 64 \pm 2 \cdot 77 * . \dagger$ \\
\hline
\end{tabular}

AA, arachidonic acid. ${ }^{*} P<0 \cdot 05$ compared with basal; $\uparrow P<0 \cdot 05$ compared with Controls.

GnRH-dependent secretion of testosterone, but only ionomycin was capable of reversing the inhibitory effect of melatonin on such secretion. The inhibitory role of melatonin on cytosolic $\mathrm{Ca}^{2+}$ concentrations was also demonstrated by direct measurement of cytosolic $\mathrm{Ca}^{2+}$ concentrations by Fura-2. Approximately one-third of the Leydig cell population responded to high-dose administration of $\mathrm{GnRH}$ with an early spike in $\left[\mathrm{Ca}^{2+}\right]$, which was not followed by a sustained plateau phase, even when bathed in $\mathrm{Ca}^{2+}$-free medium. These results are in accordance with those reported by Tomic et al. (1995), who demonstrated for the first time that only a part of the Leydig cell population is responsive to $\mathrm{GnRH}$. In our experiments, the GnRH-dependent $\left[\mathrm{Ca}^{2+}\right]_{\mathrm{i}}$ spike was reduced in a dose-dependent manner by melatonin, showing that the effect of melatonin in decreasing $\left[\mathrm{Ca}^{2+}\right]_{i}$ is in part due to a reduction in the release of $\mathrm{Ca}^{2+}$ from intracellular stores.

It has previously been shown that the inhibitory effect of melatonin on GnRH-induced LH secretion by neonatal gonadotrophs is blocked by PTX pretreatment, suggesting the involvement of an inhibitory G-protein (Vanececk 1998). Similarly, in our cells, the inhibitory effect was suppressed by pretreatment with PTX in a concentration of $180 \mathrm{ng} / \mathrm{ml}$ for $20 \mathrm{~h}$, thus suggesting the participation of the same kind of melatonin membrane receptor; indeed, Leydig cells bear melatonin receptors that are coupled to PTX-sensitive G-proteins (Valenti et al. 1997).

Although, in neonatal gonadotrophs, the negative effect of melatonin on GnRH-induced LH secretion was progressively eliminated by increasing concentrations of BAY K or A 23187 (Vanececk 1998), in our cells the inhibitory effect of melatonin on GnRH-dependent testosterone secretion was never completely reversed in any of the experiments with ionomycin; these discrepancies can be explained on the basis that, in Leydig cells, other mechanism(s) are likely to be involved in the melatonin-dependent blockade of GnRH-induced steroidogenesis. Given the fact that melatonin had been shown to be able to decrease DAG formation in pituitary cells (Dix et al. 1984), we were expecting PMA administration somehow to prevent the inhibitory role of melatonin. This phenomenon was not observed in our experiments; indeed, testosterone secretion was reduced by melatonin in the presence of factors capable either of directly activating (PMA) or of inhibiting (staurosporine) PKC activity (Foresta et al. 1995, Vanececk 1998). Similarly, administration of increasing concentrations of PMA was not able to reverse the inhibitory effect of melatonin on GnRH-dependent LH secretion in neonatal rat gonadotrophs (Didolkar \& Sundaram 1989).

The inhibitory effect of melatonin has also been observed on the testosterone secretion induced by arachidonic acid, which directly stimulates testosterone secretion independently of its cyclooxygenase and lipoxygenase products (Lin 1985, Romanelli et al. 1995).

Direct measurement of OHP concentrations confirmed that, in all the experiments, melatonin reduced the enzymatic activity along the steroidogenic pathway - an effect attributable to a block of 17-20 desmolase (Valenti et al. 199, 1997); in particular, none of the drugs administered, alone or in combination, was able to reverse this effect - not even high concentrations of ionomycin. These results suggest that the mechanism(s) implicated in the melatonin-dependent regulation of 17-20 desmolase enzymatic activity does not involve any of the mediators elicited downstream of the binding of $\mathrm{GnRH}$ to its receptor - not even changes in $\left[\mathrm{Ca}^{2+}\right]_{\mathrm{i}}$. Melatonin could, therefore, act through still unknown mechanism(s), somehow controlling the 
expression of enzymes of the steroidogenic pathway, other proteins, or both.

We conclude that melatonin reduces GnRHinduced testosterone secretion by 1) decreasing $\left[\mathrm{Ca}^{2+}\right]_{\mathrm{i}}$, through impairment of the GnRHdependent release of $\mathrm{Ca}^{2+}$ from intracellular stores, and 2) by blocking 17-20 desmolase enzymatic activity, an effect that occurs irrespective of changes in $\left[\mathrm{Ca}^{2+}\right]_{\mathrm{i}}$.

\section{REFERENCES}

Conte D, Questino P, Fillo S, Nordio M, Isidori A \& Romanelli F 1993 Endothelin stimulates testosterone secretion by rat Leydig cells. Fournal of Endocrinology 136 R1-R4.

Didolkar AK \& Sundaram K 1989 Mechanism of LHRHstimulated steroidogenesis in rat Leydig cells: lipoxygenase products of arachidonic acid may not be involved. Fournal of Andrology 10 449-455.

Dix CJ, Habberfield AD, Sullivan MH \& Cooke BA 1984 Inhibition of steroid production in Leydig cells by nonsteroidal anti-inflammatory and related compounds: evidence for the involvment of lypoxygenase products in steroidogenesis. Biochemical fournal 219 529-537.

Ellis LC 1972 Inhibition of rat testicular androgen synthesis in vitro by melatonin and serotonin. Endocrinology 90 17-28.

Foresta C, Mioni R, Bordon P, Gottarello F, Nogara A \& Rossato M 1995 Erythropoietin and testicular steroidogenesis: the role of second messengers. European Fournal of Endocrinology 132 103-108.

Foresta C, Rossato M, Nogara F, Gottardello F, Bordon P \& Di Virgilio F 1996 Role of P2-purinergic receptors in rat Leydig cell steroidogenesis. Biochemical Fournal 320 499-504.

Giusti M, Valenti S, De Rose AF, Foppiani L, Carmignani G \& Giordano G 1997 Melatonin exerts a modulatory role on androgen secretion by Leydig cells: preliminary data on in vitro cultured Leydig cells of human testis. International Fournal of Andrology 20 (suppl 1) 7.

Grynkiewicz G, Poenie M \& Tsien RT 1985 A new generation of $\mathrm{Ca}^{++}$indicators with greatly improved fluorescence properties. Fournal of Biological Chemistry 260 3440-3450.

Leung PCK \& Steele GL 1992 Intracellular signalling in the gonads. Endocrine Reviews 13 476-498.

Li YX, Rinzel J, Keizer J \& Stojilkovic SS 1994 Calcium oscillations in pituitary gonadotroph: comparison of experiment and theory. Proceedings of the National Academy of Sciences of the USA 91 58-62.

Lin T 1985 Mechanism of action of gonadotropin-releasing hormone stimulated Leydig cell steroidogenesis III. The role of arachidonic acid and calcium/phospholipid dependent protein kinase. Life Sciences 36 1255-1261.

Malgaroli A, Milani D, Meldolesi J \& Pozzan T 1987 Fura-2 measurement of cytosolic free $\mathrm{Ca}^{2+}$ in monolayer and suspension of various types of animal cells. Fournal of Cellular Biology 105 2145-2155.

$\mathrm{Ng}$ TB \& Lo LL 1988 Inhibitory actions of pineal indoles on steroidogenesis in isolated rat Leydig cells. Fournal of Pineal Research 5 229-243.

Pereira ME, Segaloff DL \& Ascoli M $1988 \mathrm{Ca}^{2+}$ is an inhibitor of adenylate cyclase in MA10 Leydig tumor cells. Endocrinology 122 2232-2237.

Putney JW \& Bird GSJ 1993 The signal for capacitative calcium entry. Cell 75 199-205.

Rasmussen H, Isales CM, Calle R, Throckmorton D, Anderson M, Gasalla-Herraiz J \& McCarty R 1995 Diacylglycerol production, $\mathrm{Ca}++$ influx, and protein kinase $\mathrm{C}$ activation in sustained cellular responses. Endocrine Reviews 16 649-681.

Romanelli F, Valenca M, Conte D, Isidori A \& Negro-Vilar A 1995 Arachidonic acid and its metabolites effects on testosterone production by rat Leydig cells. Fournal of Endocrinological Investigation 18 186-193.

Saez JM 1994 Leydig cells: endocrine, paracrine and autocrine regulation. Endocrine Reviews 15 574-626.

Scorziello A, Florio T, Bajetto A, Thellung S \& Schettini G 1997 TGF- $\beta 1$ prevents gp120-induced impariment of $\mathrm{Ca}^{2+}$ homeostasis and rescues cortical neurons from apoptotic death. Fournal of Neuroscience Research 49 600-607.

Sullivan MHF \& Cooke BA 1986 The role of $\mathrm{Ca}^{2+}$ in steroidogenesis in Leydig cells. Biochemical Fournal 236 45-51.

Tomic M, Dufau ML, Kevin JC \& Stojilkovic SS 1995 Calcium signalling in single rat Leydig cells. Endocrinology 136 3422-3429.

Valenti S, Guido R, Giusti M \& Giordano G 1995 In vitro acute and prolonged effects of melatonin on purified rat Leydig cell steroidogenesis and adenosine $3^{\prime}, 5^{\prime}$-monophosphate production. Endocrinology 136 5357-5362.

Valenti S, Giusti M, Guido R \& Giordano G 1997 Melatonin receptors are present in adult rat Leydig cells and are coupled through a pertussis toxin sensitive G-protein. European Fournal of Endocrinology 136 633-639.

Vanececk J 1998 Cellular mechanisms of melatonin action. Physiological Reviews 78 687-721.

REVISED MANUSCRIPT RECEIVED 4 June 1999 